\title{
Shared Governance at Community Colleges: Challenges and Successes
}

\section{Stacey Lee Donohue}

The author is chair of the Department of Humanities and professor of English at Central Oregon Community College. A version of this paper was presented at the 2012 MLA convention in Seattle.
A FEW years ago, I served on a search committee to fill two instructional dean positions at my community college. Because these were entry-level positions and because we required candidates to have full-time faculty and college leadership experience, nearly all the candidates were faculty members who had been department chairs at two-year colleges. We interviewed ten candidates. One question we asked was, How do you define shared governance? A few candidates struggled to respond to the question, but most seemed to have some understanding of the concept. What surprised me, though, were these responses:

A program director said that most faculty members do not want to be involved in decision making, so although he offers them a voice, he makes all the decisions.

A department chair claimed that administrators, not faculty members, are paid to do governance work.

Another chair noted that since elected boards and the president have the ultimate responsibility in making sure the college is meeting its mission, they alone have decision power. Thus shared governance cannot legally exist.

Of course I should not have been surprised: several of my colleagues have also complained that shared is a false term because faculty members have only an advisory role in governance.

A 2003 study by Sue Kater and John Levin that examined collective bargaining contracts at community colleges across the United States and Canada sheds some light on these responses: the researchers discovered that only $50 \%$ of collective bargaining contracts explicitly define shared governance and detail how it functions. Most do not even mention it; the term is relatively recent, referring to faculty participation in decision making. Yet the contracts tend to indicate some level of participatory governance. Kater and Levin concluded that, with a few exceptions, shared or participatory governance was evident or implied in most of the contracts they reviewed. Faculty members have an advisory role in college governance at the operational level (at many community colleges, boards often focus on setting broad policy) and a decision-making role in certain, clearly defined areas-for example, grievance, program budgeting, curriculum, faculty evaluation, tenure and promotion, and sabbaticals. A handful of community colleges explicitly include faculty members in institutional budget allocation decision making. The range of shared governance they found-no role, advisory role, some role, true participatory or shared decision making - reflects the range at all institutions, not just community colleges, and reveals the disconnect between the term and the practice.

(C) 2014 Stacey Lee Donohue

CrossRef DOI 10.1632/adfl.43.1.58 
Shared Governance at

Community Colleges:

Challenges and Successes

Stacey Lee Donohue
So is there shared governance at community colleges? The question is difficult to answer, given the many ways of defining and implementing shared governance on campuses, each campus having its own mission, institutional history, and customs. Although many factors affect how shared governance was originally constructed at two-year colleges (control state or local, board members elected or appointed, property taxation or not, shared governance voluntary or mandated, and so on), most community colleges were established on the $\mathrm{K}-12$ bureaucratic model rather than on the ideal university model of a community of scholars and consensual decision making (Collins; Jenkins and Jensen).

John Levin notes that the pyramid structure for governance was the norm until the transition to some form of sharing began in the 1970s, for two reasons: the AAUP 1966 statement calling for "shared responsibility and cooperative action" (1996 Statement) and an increase in collective bargaining units. By the 1980s and 1990s, enrollment growth, economic security, and management's move to more team-building business practices also led to revised governance models at many community colleges throughout the country (Kater and Levin 4). At the same time, faculty members wanted more meaningful involvement, particularly after recognizing that although collective bargaining could improve working conditions, it did not necessarily guarantee participation in strategic decision making (Alfred).

Another influence came from California. In the late 1980s, in an attempt to move the 108 community colleges in California away from their K-12 roots, California Assembly Bill 1725 was enacted, which increased faculty responsibility in governance in academic matters through academic senates, requiring management to allow faculty participation and to "consult collegially" with faculty members (Collins 37). This legislation identified other changes in the California community college system: raising minimum faculty qualifications, extending the faculty probationary period from two years to four, requiring peer review of faculty members, and establishing funding streams for professional and curricular development. The goal was to increase confidence in the integrity of the associate in arts degree and professionalize the community college faculty. State funds were to be contingent on "collegial governance" (37).

Despite the legislation, shared governance was not completely successful at all California community colleges, as Linda Collins notes, for a variety of reasons: backlash from autocratic structures and models, including boards resistant to change; lack of enforcement of the law; and lack of funding for faculty or administration training in how to effectively accomplish shared or collegial governance.

Further obstacles_-or, more accurately, disturbing trends-became evident in the 1990s:

a regional accreditation process with a focus on student learning outcomes leading to a state-mandated standardization of the curriculum that effectively undermines faculty decision making in an area that is historically faculty-controlled increased reliance on part-time faculty members and a decrease in full-time faculty positions, leading to an increased workload for full-time faculty members

increasing hostility to what is perceived as extra work rather than an integral part of a faculty member's role 
Shared Governance at

Community Colleges:

Challenges and Successes

Stacey Lee Donohue
Other challenges are embedded in the very nature of shared governance: it slows decision making, limits efficiency, and contributes to role confusion. Shared governance adds to the responsibility of administrators but also reduces their authority; it can make teaching a secondary responsibility for those faculty members who are deeply involved in decision making (Alfred). At community colleges that give rank and tenure, active engagement in shared governance work is typically a requirement. Faculty members suited for such work tend to chair major committees of the college, time-consuming work that often detracts from department service, which can cause resentment. On the other hand, faculty members who dislike shared governance work and would prefer to focus entirely on the classroom are often required to participate, a requirement that creates a hostility toward the entire process and that can undermine it.

California's legislation was intended to make community college faculty members more responsible for governance than $\mathrm{K}-12$ faculty members and thus more professional, but often that is not the result. Rob Jenkins and Beth Jensen fear that a high school mentality, the expectation of a "bureaucratic model" of governance, common within the K-12 school system, rather than a shared decision-making model pervades many two-year college campuses, among administrators and faculty members both: overworked, neither have the time and energy needed to share responsibility. Of most concern is that we can no longer assume that newer faculty members and administrators value the practice of shared governance.

The advantages of shared governance are that faculty members buy into the system and that being part of strategic planning and decision making boosts morale. Participating in shared governance also increases faculty understanding of the issues facing a college and improves communication between administration and faculty; it fosters collegiality and creates a sense of common purpose. When there are many viewpoints, faculty engagement, administrative support, and open communication, a college is better able to anticipate and respond to change. That the president or the board retains final say over most decisions does not mean that the president or board makes all the decisions. In the 1990s, many community college boards adopted the policy governance model, which allowed them to focus on creating a vision for the organization, leaving the day-to-day operations and decisions to staff members, administrators, and faculty members.

We who teach and do research need to be included in the running of the college: abdicating that role for whatever reason could return us to the corporate hierarchy model of governance, which will undermine the academic freedom that we expect. The disempowerment or disengagement of faculty contributes to the increase in administrative, managerial positions on many campuses.

I am a strong advocate for faculty involvement in campus governance, yet the voices of those dean candidates and of other faculty members on my campus (that faculty members do not care, that shared governance is illegal, that advisory roles are not decision-making roles, etc.) can't be dismissed. So how do we develop, maintain, or strengthen a system of shared or participatory governance in response to such opinions? The first step faculty members should take on their campuses is to start the process of coming to a campus-wide agreement on the value of, process of, and 
Shared Governance at

Community Colleges:

Challenges and Successes

Stacey Lee Donohue appropriate name for that system (participatory, collegial, shared governance). That first step is not easy.

My community college is still small enough that faculty members and administrators work together regularly under collegial conditions, but during times of fiscal, enrollment, or accreditation stress those conditions become fragile, especially when there is no definition of shared governance that all agree to. I pointed out to college administrators that despite talk about shared governance on campus, our policy-andprocedures manual does not use the term; instead, it refers indirectly to the value of representative government. I worked with colleagues to draft a definition (see app.) to present to College Affairs, a governance committee that consists of the college president, representatives from the board, administrators, faculty members, staff members, and students. Before it reached the committee, my definition went through three drafts, each one gently watering down the faculty role in decision making. One suggested revision deleted "faculty has primary responsibility" and replaced it with "faculty and administration share responsibility." I was told that everything should be shared at the operational level, including areas historically reserved for faculty members. I was using the language I had found in other colleges' policyand-procedures manuals, but it is true that at my institution responsibility is indeed shared: committees for curriculum, tenure and promotion, and sabbaticals, while mostly composed of faculty members, always include at least one administrator, and there is usually one faculty member on the committees (very few) composed mostly of administrators. Though I interpreted committees in areas historically under some sort of faculty control as "faculty has primary responsibility," administrators see their appointment to such committees as a way to implement the shared part of the governance structure, if only so that they can submit progress reports to other administrators and share the administrative perspective with faculty members, keeping two-way communication open. There are faculty members, however, who see an administrative representative on a committee as a spy meant to curb faculty decision making.

Adding a clear definition to the policy-and-procedures manual (as well as to the collective bargaining agreement) is a first step only. In order that shared governance be preserved and strengthened, the following needs to happen:

The principles of shared governance must be clarified and shared. If there is no understanding of why a college embraces some version of shared governance, shared governance will continuously be under threat, from both within and without.

The process of shared governance and the roles of all participants must be clear.

Adjunct and non-tenure-track faculty members must be included in the process and compensated for participating.

Colleges need to provide all participants release time, encouragement, information, and training.

Regional accreditors should support shared governance by providing standards.

A recent issue of Pedagogy contains a cluster of short essays on shared governance. In one, Mary McAleer Balkun notes that impatient administrators and inadequately engaged faculty members have always existed. Michael Bérubé, a former MLA president and someone who is quite engaged, admitted in his talk on shared governance 
Shared Governance at

Community Colleges:

Challenges and Successes

Stacey Lee Donohue at the 2012 MLA convention that it took Penn State's recent child abuse scandal to motivate him to participate more actively in campus affairs ("Keeping”). In the same issue of Pedagogy, Elizabeth Langland offers a caveat that echoes Bérubé's New York Times editorial ("At Penn State") on the need for Penn State faculty members to become more involved in shared governance: shared governance will "work only if faculty embrace change before it is mandated and come forward with suggestions for solving our challenges before we are asked. . . . [F] aculty governance must cease to be reactive and become anticipatory, leading institutional transformation rather than lamenting it" (556-57). Instead of complaining about administrative bloat or state mandates, faculty members need to be vigilant, proactive, and involved. Administrative rule kicks in when there is a vacuum: faculty members must not allow that vacuum to exist.

At my community college, we ultimately hired two of the instructional dean candidates who strongly believed and actively engaged in some version of shared governance at their respective campuses. Four of the eight search committee members were faculty members. Candidates' responses to the question, What is shared governance? informed our selection. Yes, we are a relatively small campus and for the most part there is trust between faculty and administration, and, yes, our hiring decision is only one example, but it gives me hope.

Last year, our Faculty Forum (an in-house collective bargaining unit) formed the Shared Governance Task Force. Working with a group of administrators and staff members, we solidified a definition of shared governance that we all hope will be useful in continuing our college-wide discussion of its value at a community college.

\section{Works Cited}

Alfred, Richard L. "Shared Governance in Community Colleges." Educ. Commission of the States. Center for Community Coll. Policy, Sept. 1998. ERIC. Web. 15 Sept. 2011.

Balkun, Mary McAleer. "Making Shared Governance Work: Strategies and Challenges.” Pedagogy 11.3 (2011): 562-69. Print.

Bérubé, Michael. “At Penn State, A Bitter Reckoning.” New York Times. New York Times, 17 Nov. 2011. Web. 4 Feb. 2014.

- "Keeping the Lights On: Shared Governance in the Corporate University." MLA Annual Convention. Sheraton Hotel, Seattle. 4 Jan. 2012. Address.

Collins, Linda. "Shared Governance in the California Community Colleges." Academe 88.4 (2002): 36-40. JSTOR. Web. 20 Dec. 2011.

Jenkins, Rob, and Beth Jensen. "How to Climb Down from Top-Down Leadership." Academe May-Apr. 2010. Web. 20 Dec. 2011. <http://www.aaup.org/AAUP/pubsres/academe/2010/MJ/feat/jenk.htm.>

Kater, Sue, and John S. Levin. "Shared Governance in the Community College." Community College Journal of Research and Practice 29.1 (2005): 1-23. ERIC. Web. 17 Mar. 2014.

Langland, Elizabeth. "Shared Governance in an Age of Change." Pedagogy 11.3 (2011): 554-57. Print.

Levin, John S. "What's the Impediment? Structural and Legal Constraints to Shared Governance in the Community College." Canadian Journal of Higher Education 30.2 (2000): 87-122. Print.

1966 Statement on Government of Colleges and Universities. American Association of University Professors. AAUP, n.d. Web. 5 Feb. 2014. 
Shared Governance at Community Colleges:

Challenges and Successes

Stacey Lee Donohue
Appendix: Definition of Shared Governance at Central Oregon Community College

Article G-6-O of the college's General Procedures Manual (http://www.cocc.edul general-procedures-manual/generall); revised 12 November 2013.

Central Oregon Community College values shared governance. Shared governance entails full and active participation by faculty members, administrators, staff members, and students, who share responsibility as equal stakeholders for the mission, vision, goals, academic integrity, and institutional sustainability of the college. This mutual responsibility requires that stakeholders engage in free and open discussion, join in collaborative decision making, and mutually inform one another of resolutions.

College committees have been established to implement present policies and procedures and to plan for the future. Committee members, consisting of elected or appointed members from the various areas on campus, collaborate in the decisionmaking process on broad curricular, academic, and policy issues.

Some primary responsibilities for implementation and decision making reside with particular stakeholders. The guiding principle is that institutional policy making is done in collegial collaboration with respective college stakeholders and their representatives.

Shared governance requires that all such decisions be communicated effectively to the general college community, with special emphasis on the need for accountability with timely, reasoned explanations for any modification or rejection of recommendations.

In order to be effective, shared governance requires respect for the process and for all participants, open communication, and a mutual basis of trust that enables all to express their views freely with the expectation that their contributions will carry weight in the decision-making process. 